OPEN ACCESS

Edited by:

Moshe Semyonov,

Tel Aviv University, Israel

Reviewed by:

Rebeca Raijman,

University of Haifa, Israe

Dina Maskileyson,

Universität zu Köln, Germany

${ }^{*}$ Correspondence:

Karin Amit

karina@ruppin.ac.

Specialty section:

This article was submitted to

Sociological Theory,

a section of the journal

Frontiers in Sociology

Received: 17 July 2018 Accepted: 25 October 2018 Published: 19 November 2018

Citation:

Amit $K$ and Chachashvili-Bolotin S

(2018) Satisfied With Less? Mismatch

Between Subjective and Objective

Position of Immigrants and

Native-Born Men and Women in the

Labor Market. Front. Sociol. 3:33.

doi: 10.3389/fsoc.2018.00033

\section{Satisfied With Less? Mismatch Between Subjective and Objective Position of Immigrants and Native-Born Men and Women in the Labor Market}

\author{
Karin Amit* and Svetlana Chachashvili-Bolotin \\ The Institute for Immigration and Social Integration, Ruppin Academic Center, Hadera, Israel
}

The current study introduces a new mismatch concept in labor studies, the mismatch between subjective work perceptions and actual labor market position, and examines it from the perspectives of gender, ethnic and migration. This mismatch, positive or negative, was examined among men and women from different ethnic groups in Israel, both immigrants and native-born. The analyses were conducted on 9,923 employees using the Israeli CBS Social Surveys (2013-2015). The results reveal that the gender effect is more prominent than the ethnicity and migration effect. In general, women were more satisfied with their actual position in the labor market (positive subjective mismatch) than men, and men were less satisfied with their actual position in the labor market (negative subjective mismatch) than women. A positive subjective mismatch was also found among men from disadvantaged ethnic and immigrant groups. The multivariate analyses revealed that after controlling for socio-economic variables, ethnic differences declined among both men and women. Possible explanations are discussed, primarily based on the notion of relative well-being in respect to workers' expectations.

Keywords: immigrant's labor market integration, subjective work perceptions, gender, ethnicity, mismatch in the labor market

\section{INTRODUCTION}

The labor market serves as a central arena of an immigrant's integration. Migration researchers have implied that newly arrived immigrants often experience a downward mobility in their economic status and labor market position, but for many of them, position in the labor market significantly improves over time (Chiswick, 1982; Borjas, 1990; Kogan, 2003). Studies documenting the integration of immigrants in the labor market focus mainly on objective parameters such as earnings and occupational attainment (Chiswick, 1982; Borjas, 1990; Chiswick and Miller, 2002; Cohen and Kogan, 2007; Gorodzeisky and Semyonov, 2011). These studies highlight the importance of comparing the immigrant's economic position to that of other groups, and point to variation in the economic position of different immigrant groups. However, these prominent migration studies ignore the subjective parameters associated with the immigrant's integration into the labor market, and disregard questions related to the immigrants' satisfaction with their position in the labor market. 
In recent years, subjective well-being parameters such as life satisfaction and happiness are gaining more attention from migration scholars (McMichael and Manderson, 2004; Amit, 2010, 2012; Bartram, 2011), and some studies specifically relate to immigrants' satisfaction from their position in the labor market (Jong et al., 2002; Amit and Riss, 2014). Yet, there has been no comprehensive study that analyzes and compares both subjective and objective parameters of the labor market integration of immigrants. This comparison invites questions related to the match or mismatch between these parameters, and asks whether there are differences based on gender, ethnicity and migration. In other words, are women more (or less) satisfied with their actual position in the labor market than men? Are certain ethnic and immigrant groups more (or less) satisfied with their actual position in the labor market? And which variables predict this mismatch? The present study addressed these questions by introducing a new concept of labor market mismatch. We examine the mismatch between both types of parameters among men and women, as well as among different groups of immigrants and native-born Israelis.

This paper contributes to the labor market literature on the integration of immigrants and ethnic minorities, and to the literature on gender differences in the labor market. The contribution is three-fold. First, we introduce a new concept that enables analyzing simultaneously both objective and subjective labor market parameters. The current literature on objective and subjective labor market integration has developed in parallel but hardly any cross-fertilization has occurred. Our new mismatch concept creates synergy between these two strands of research. Second, we implement the mismatch concept on native-born, immigrants and ethnic minorities of both genders. This enhances our understanding of the labor market integration of groups holding different positions in the labor market. Third, we add to the empirical knowledge on immigration, ethnicity and gender in the Israeli context. To date, most of the knowledge on ethnic differences in Israel is based on studies targeting selected groups of immigrants and ethnic minorities, many of them using panethnic classifications. Our data set, merged for the purpose of this study by the Central Bureau of Statistics (CBS), enables us to examine a detailed and representative sample of the different groups comprising the Israeli population, both immigrants and native-born.

We begin this introduction by presenting the Israeli case, after which we provide the theoretical background related to labor market integration of different groups. Following this we present our new mismatch concept and our research hypotheses.

\section{The Israeli Case}

Israel presents an interesting case study of a multi-ethnic society. Out of Israel's current population of 8.8 million, about 80 percent are of Jewish ancestry and 20 percent are Arabs (CBS, 2007). The Jewish population is ethnically diverse and includes immigrants from various origin countries (about 40 percent are foreignborn), second-generation Israeli-born from Asian-African origin (Mizrahim) and European-American origin (Ashkenazim), and Israeli-born to Israeli-born parents (third or more generation). In the present study, we examine the labor market integration of the main groups comprising the Israeli population: four immigrant groups (Former Soviet Union immigrants, Ethiopian immigrants, Western immigrants, and veteran immigrants who immigrated before 1989) and four Israeli-born groups (secondgeneration Mizrahim, second-generation Ashkenazim, thirdgeneration Israeli-born, and Arabs). Each group is described below.

The Former Soviet Union (FSU) immigrants, who arrived in Israel over the past two decades, comprise the largest immigrant group. More than one million immigrants came to Israel after the collapse of the Soviet Union in 1989, mainly due to economic and political uncertainty in their countries of origin (Lissitsa et al., 2002; Ben-Rafael et al., 2006; Chachashvili-Bolotin, 2007; Remennick, 2013). Studies on this population emphasize the high levels of human capital with which these immigrants arrived in Israel. These studies have documented impressive employment levels for these immigrants, but partly at the cost of occupational downgrading compared with the occupations they held in the FSU (Raijman and Semyonov, 1997; Gorodzeisky and Semyonov, 2011). Evidence from studies examining social and subjective parameters indicates that FSU immigrants place great emphasis on their Russian culture and identity (Lissitsa et al., 2002; BenRafael et al., 2006; Remennick, 2013) and are less satisfied with life in Israel compared to other recent immigrant groups (Amit, $2010)^{1}$.

Ethiopian immigrants arrived in Israel in two main waves during the 1980s and 1990s. Today, the number of Ethiopians in Israel, both immigrants and Israeli-born, stands at about 140,000 (CBS, 2007). Unlike other immigrant communities in Israel, the Ethiopian community suffered from meager human capital: many of the arriving immigrants were uneducated and their familiarity with educational and employment settings in modern society was very limited (Shabtay, 2001). These conditions, combined with claims of race discrimination, delayed their labor market integration. Studies indicate that the Ethiopians are the least integrated of all of Israel's immigrant groups in education and economic position, yet their subjective well-being is relatively high compared to other immigrant groups (Semyonov et al., 2007). In these studies, as in the current study, first- and secondgeneration Ethiopian immigrants are addressed as one ethnic group.

The Western segment of immigrants includes those from Western Europe and the Americas (primarily France, the United States, and South America) who immigrated to Israel after 1989. The majority of Western immigrants moved to Israel for ideological reasons-Zionism and religion-or because of economic and social insecurity (Amit and Riss, 2007; Chachashvili-Bolotin and Lissitsa, 2016). These immigrants are characterized by high levels of human capital (Amit and Riss, 2007; Gindin et al., 2009). Whereas English-speaking immigrants

\footnotetext{
${ }^{1}$ In the present study we examine FSU immigrants. Because we focus on workers aged 25-60, and most immigrants from the FSU arrived after 1989, the number of second-generation FSU immigrants is very small in our data set. Thus they are not examined separately and the few individual cases were added to the overall FSU group. It is important to note that the number of second-generation FSU immigrants in the working age population is small as well.
} 
have a significant advantage in the Israeli labor market, the labor market integration of French- and Spanish-speaking immigrants is more challenging and involves transnational employment patterns (Amit and Bar-Lev, 2015). These immigrants also report high levels of subjective well-being, partially explained by their immigration motives and religiosity (Amit, 2010). Immigrants who arrived from other various countries before 1989 can be classified as "veterans" and do not have a specific ethnic or socioeconomic profile. Most of them arrived in Israel as children or adolescents (1.5 generation). This group includes Soviet Jewish immigrants who arrived in the 1970s, Moroccan Jews who arrived in the late 1960s, and immigrants from other countries around the globe. We added this group in order to portray a representative sample of the Israeli immigrant population.

When studying the Israeli-born population, it is important to differentiate between Arabs and Jews. By law, Israeli-Arab citizens are entitled to the same civic rights as the Jewish population. But compared to Jews, the Arab minority is disadvantaged in the labor market in terms of occupational status, wage level, and the allocation of public resources (Semyonov and Levin-Epstein, 1987; Yashiv and Kasir, 2013). The labor market participation rates of Israeli-Arabs, and especially of women, are low relative to those of Israel's Jewish population (Yashiv and Kasir, 2013), and although there has been an increase in labor market participation rates, many Arab women are employed in ethnic enclaves within their communities (Khattab, 2002).

A very common classification of the Jewish population is based on continents of origin; those from Asia-Africa are referred to as Mizrahim, while those from Europe-America are referred to as Ashkenazim. Whereas the ethnicity of Israeli-born to Israeli-born parents (third or more generation of immigrants) cannot be detected, allowing this growing group to serve as a baseline category, the ethnicity of the second generation can be measured. The socio-economic gap between Mizrahim and Ashkenazim has been extensively studied over the past few decades (Lewin-Epstein and Semyonov, 1986), and although the educational gaps between the two groups have narrowed, there is evidence for earning gaps between the dominant Ashkenazi group and the Mizrahi group, partially explained by the growing inequality in Israeli society (Cohen and Haberfeld, 2007). A recent study, focusing on the earnings disadvantage of different ethnic groups in Israel, reveals that the earning penalties among second-generation Mizrahi immigrants can be attributed to their ethnicity (Semyonov et al., 2015).

\section{THEORETICAL BACKGROUND}

\section{Labor Market Integration-Objective and Subjective Parameters}

For many years, researchers have studied the integration of immigrants into the host country from an economic perspective that focuses on labor market performance. The expectation of migrants to succeed in the new labor market is usually a significant factor in their decision to immigrate and in their willingness to pay the social and economic price of leaving their countries of origin (Chiswick, 1982; Borjas, 1990; Gorodzeisky and Semyonov, 2011).Yet, after their arrival, the majority of immigrants face difficulties in the new labor market due to their lack of language proficiency, inadequate skills and qualifications, limited access to information and knowledge, and lack of local social networks. These difficulties diminish over time for many immigrants, and their position in the labor market improves (Chiswick, 1982; Borjas, 1990; Kogan, 2003). According to this literature (based on mainstream theoretical frameworks, notably human capital and status attainment traditions in economics and sociology), successful integration occurs when immigrants reach the same earnings as native-born possessing identical characteristics, and move into more prestigious occupations that better fit their skills and qualifications (Chiswick, 1982; Borjas, 1990; Gorodzeisky and Semyonov, 2011).

Labor market performance and position in the labor market may vary across groups for both immigrant groups and nativeborn. Hence, studies on immigrants' labor market incorporation documented and compared the labor market position of different ethnic groups (Bloom et al., 1994; Tubergen et al., 2004) and their relative mobility over time (Gorodzeisky and Semyonov, 2011). Differences between immigrant and native-born groups in the labor market may be attributed to their characteristics (socio-demographic, human capital) and to their migration circumstances and motives, as well as to context of reception in the host country (Nee and Sanders, 2001; Kogan, 2003; Portes and Rumbaut, 2006; Cohen and Kogan, 2007). Nee and Sanders (2001) proposed a model according to which the social, financial, and human-cultural capital of immigrant families predict the sorting of immigrants into various labor market trajectories. Their study, conducted in the US on Asian immigrants from different origin countries, shows that the mix of capital immigrants arrive with, and subsequently accumulate, shapes the trajectory of their incorporation into the host society.

Gender is an important demographic factor to be considered when examining labor market integration. For many years, the literature on the economic integration of immigrants in the labor market tended to focus on migrant men, but it is becoming more evident that migrant women play a central role in the global migration movements of workers and in the host country's labor market (Curran et al., 2006; Castles and Miller, 2013). Previous studies pointed to the double disadvantage of migrant women in the host country's labor market as both women and migrants (Raijman and Semyonov, 1997). However, globalization processes have led to the emergence of new employment opportunities and patterns that allow migrant women to be more proactive and improve their position in the labor market (Curran et al., 2006).

The dominant approach in the research reviewed so far has been to evaluate the immigrant's labor market performance by objective extrinsic measures, mainly earnings and occupational attainment, and not by subjective intrinsic measures that are based on the immigrant's perceptions and feelings of satisfaction with their position in the labor market. Our study suggests adding the subjective parameters to the evaluation of the immigrant's 
integration in the labor market, and comparing the objective labor market performance to the subjective perception related to it.

Subjective well-being in general, and specifically life satisfaction, is the focus of recent migration studies (Jong et al., 2002; Massey and Akresh, 2006; Amit, 2010; Lissitsa and Chachashvili-Bolotin, 2016a,b). Life satisfaction, a main component of subjective well-being, refers to the cognitive judgment aspect of the concept, and is defined as an overall assessment of an individual's quality of life according to his/her personal judgment and criteria (Shin and Johnson, 1978; Diener, 1984; Diener et al., 1985). Migration studies found that various factors influence an immigrant's life satisfaction, which varies across ethnic and immigrant groups (Phinney et al., 2001; Amit, 2010).

Studies also emphasize that the immigrants' life satisfaction does not necessarily match their objective socioeconomic position in the new country. In a study conducted in Israel on elderly immigrants, it was found that immigrants from certain ethic groups characterized by high socio-economic background were not necessarily more satisfied with their lives compared to immigrants from different ethnic groups characterized by lower socio-economic background (Amit and Litwin, 2010). Studies on Mexican immigrants in the US found that subjective well-being played a central role for these immigrants, and they were willing to compromise for less rewarding jobs (Shinnar, 2007).

Notwithstanding, individuals may also express satisfaction with specific aspects of their lives (Solberg et al., 2002), and specifically, satisfaction from their working lives. Job satisfaction, a well-researched concept in organizational studies, has been defined as a global construct regarding general feelings about the job (Lock, 1976). More recent studies examine job-related well-being as a central part of the workers subjective well-being, and refer to how the workers feel toward their jobs (Horn et al., 2004; Warr, 2013). These subjective work perceptions are receiving less attention from migration scholars (Ea et al., 2008), although there is evidence that these perceptions are linked to the immigrant's acculturation process (Au et al., 1998). In the current study we focus on the individual's satisfaction from work-related parameters. Few studies attempted to examine immigrants' work perceptions, and imply that these perceptions are not necessarily in accordance with their actual labor market position (Valdivia and Dannerbeck, 2009; Valdivia and Flores, 2012). The mismatch between subjective work perceptions and actual labor market position is the focus of our study.

\section{Mismatch Between the Subjective and Actual Positions in the Labor Market}

The mismatch concept in labor market studies is traditionally related to the imperfect matching between education and jobs, and presents forms of over-education and under-education (Chevalier, 2003; Aleksynska and Tritah, 2013; McGowan and Andrews, 2015). The literature offers multiple theoretical explanations for this mismatch, based on imperfect information and imperfect screening of workers' qualifications by employers
(Sicherman, 1991; Groot and Van Den Brink, 2000; Leuven and Oosterbeek, 2011). Migration scholars examine this educationoccupation mismatch among immigrants in comparison to native-born, and point to the more intense mismatch among immigrants (Chiswick and Miller, 2009, 2012; Aleksynska and Tritah, 2013). In these migration studies, additional explanations for the mismatch are provided, based on supply and demand processes and determinants related to the home country of immigrants and to the destination country. The measure of the education-occupation mismatch is based on a classification of three components: over-education, match, and undereducation (Chiswick and Miller, 2012; Aleksynska and Tritah, 2013).

Our study introduces a new and different concept of mismatch in the labor market: the imperfect matching between the actual position in the labor market and the subjective perceptions related to it. Following the classification of the educationoccupation mismatch by migration scholars (Chiswick and Miller, 2012; Aleksynska and Tritah, 2013), we suggest two forms of the perceptional mismatch: positive and negative subjective mismatch. Positive subjective mismatch occurs when an individual's perceptions are higher than their actual position in the labor market, and negative subjective mismatch occurs when an individual's perceptions are lower than their actual position in the labor market. Our study examines whether there are perceptual differences based on gender, ethnicity and migration, and detects variables predicting positive and negative subjective mismatch.

Valdivia and Dannerbeck (2009) conducted a case study among Mexican immigrant women in the US and found that although their wages had not increased, they perceived that their position in the labor market was improving. In our terms, their study presents a positive subjective mismatch for women who are from a low-class ethnic group. The women in this study were satisfied simply by being employed, and compared their position to their prior living conditions and to the possibility of unemployment (Valdivia and Dannerbeck, 2009). Another study, conducted on a British survey, found that although women's jobs were inferior to men's in objective scales, women reported higher levels of job satisfaction than did men (Clark, 1997).

These studies present a gender paradox related to job satisfaction that is called "the paradox of the contented female worker." According to this paradox, women tend to be more satisfied with their job and with their wage than men, although their position in the workplace is less favorable (Clark, 1997; Sousa-Poza and Sousa-Poza, 2000, 2007; Davison, 2014). Since satisfaction is partly determined by the discrepancy between what one wants and what one gets, this gender gap in favor of women has been attributed in many studies to psychological explanations. Studies point to women's lower job expectations (Mora and Ferrer-i-Carbonell, 2009) and to gender differences in perceptions of fair wages (Mueller and Kim, 2008). As Clark emphasized, “women's higher job satisfaction does not reflect that their jobs are unobservable better than men's, but rather that, perhaps because their jobs have been so much worse in the past, they have lower expectations" (Clark, 1997, p. 365). Clark's 1997 explanation relies on the 
concept of relative well-being, especially with regards to workers' expectations. According to this explanation, an identical man and woman with the same jobs and expectations would indeed report identical job satisfaction. but since women's expectations are relatively lower than men's, the gap appears (Sousa-Poza and Sousa-Poza, 2007; Clark et al., 2009). This gender paradox is dynamic and may disappear for women with higher job expectations. Indeed, it was found that the gender satisfaction differential was less apparent for young, highereducated, and professional women (Clark, 1997; Mueller and Kim, 2008).

A recent study conducted in Germany suggests a structural explanation for the paradox (Valet, 2018), that may be congruent to the concept of relative well-being. Valet (2018) found that in general, men and women do not differ in their perceptions of justice related to their wages. The study revealed that the gender paradox was only detectable in occupations with a considerable number of female referents, and not in maledominated occupations. Thus, their study concluded that gender differences in justice perceptions can be explained by structural explanations related to certain occupations. Our study compares the subjective perceptions related to the position in the work place (satisfaction with the job and wage) for both men and women in various occupations, with their actual position in the work place (wage and occupation). We adopt the relative wellbeing notion related to workers' expectations, as this explanation is more dynamic and may also be in congruence with the structural explanation. Women working in female-dominated occupations may express lower job expectations than women working in male-dominated occupations due to the different reference group of workers. Thus, the structural explanation may involve a subjective evaluation related to expectations.

The gap between the objective performance in the labor market and the subjective perceptions of it has never been examined previously among immigrants or ethnic minorities. Therefore, we have no theoretical basis on which we may rely. But we assume that the paradox presented above may also be apparent for the less advantaged groups in the labor market. Previous studies in the US found that students from less advantaged ethnic minorities perceived significantly greater educational and career-related barriers than their EuropeanAmerican counterparts, and thus had lower work expectations and lower sense of self-efficacy (McWhirter, 1997; Luzzo and McWhirter, 2001). As was found for women, as a result of these lower expectations, disadvantaged ethnic groups may express more positive perceptions regarding their position in the labor market. Thus, we can pose the following three research questions: (1) Is a positive subjective mismatch more typical for women than for men, whereas a negative subjective mismatch is more typical for men than women? (2) Is a positive subjective mismatch more apparent among disadvantaged ethnic groups (including immigrant groups), whereas a negative subjective mismatch is apparent more among advantaged ethnic groups? (3) Which variables affect positive and negative subjective mismatch?

Based on the above theoretical background and the description of Israeli society, we formulated the following hypotheses:

\section{Research Hypotheses \\ Gender Differences}

H1a: A positive subjective mismatch is more typical for women than for men.

H1b: A negative subjective mismatch is more typical for men than for women.

\section{Ethnic Differences}

Differences between ethnic and immigrant groups:

H2a: A positive subjective mismatch is more apparent among disadvantaged ethnic and immigrant groups (secondgeneration Mizrahim, Ethiopians immigrants, and Arabs) compared to more advantage ethnic groups (secondgeneration Ashkenazim and third- generation Israeliborn).

H2b: A negative subjective mismatch is more apparent among more advantaged ethnic groups (second-generation Ashkenazim and third-generation Israeli-born) compared to disadvantaged ethnic and immigrant groups (secondgeneration Mizrahim, Ethiopians immigrants, and Arabs).

We found it challenging to determine the mismatch pattern for FSU immigrants, as generally these immigrants can be characterized as highly educated, but many are not employed according to their qualifications and express relatively high dissatisfaction from their life in Israel (Amit, 2010; Gorodzeisky and Semyonov, 2011).

\section{METHODS}

\section{Source of Data}

Israel's CBS conducts an annual cross-sectional social survey (known as the "CBS social survey"). The data used in this study were collected from the CBS social surveys from 2013, 2014, and 2015. The social survey questionnaire was composed of a core questionnaire of about 100 items covering the main areas of life, such as socio-demographic characteristics of household members, economic situation, and employment; and skills such as education level. The interviews were conducted in Hebrew, Russian, and Arabic, according to the language used in the household.

\section{Population and Sampling Method}

The population of the CBS social survey includes permanent residents of Israel aged 20 and older, including those residing in immigrant absorption centers, student dormitories, independent living projects for the elderly, and other non-custodial institutions. To be included in the survey population, new immigrants must have resided in Israel for at least 6 months.

The CBS social survey sample includes about 7,500 persons each year, representing about 4.5 million people in the 20 and over age bracket. The response rate was around $80 \%$. Groups were defined based on three combined demographic variables: population group (Israeli-born Jews, immigrants, and Arabs), age, and gender. The size of each design group was calculated to be proportional to its size in the population. The social 
TABLE 1A | Socio-demographic characteristics of the sample-Women.

\begin{tabular}{|c|c|c|c|c|c|c|c|c|c|c|}
\hline & & $\begin{array}{l}\text { FSU } \\
\text { Imm. }\end{array}$ & $\begin{array}{l}\text { Ethiop. } \\
\text { Imm. }\end{array}$ & $\begin{array}{l}\text { Western } \\
\text { Imm. }\end{array}$ & $\begin{array}{l}\text { Veteran } \\
\text { Imm. }\end{array}$ & $\begin{array}{l}\text { Sec. Miz. } \\
\text { Imm. }\end{array}$ & $\begin{array}{l}\text { Sec. Ashk. } \\
\text { Imm. }\end{array}$ & $\begin{array}{c}\text { Third } \\
\text { generation }\end{array}$ & Arabs & Total \\
\hline$N$ & & 783 & 83 & 85 & 305 & 1,171 & 589 & 1,094 & 549 & 4,659 \\
\hline Ethnicity & & $16.8 \%$ & $1.8 \%$ & $1.8 \%$ & $6.5 \%$ & $25.1 \%$ & $12.6 \%$ & $23.5 \%$ & $11.8 \%$ & $100 \%$ \\
\hline \multirow[t]{2}{*}{ Age } & Mean & 41.78 & 36.34 & 38.00 & 49.15 & 43.07 & 42.09 & 35.45 & 37.97 & 40.52 \\
\hline & $S D$ & $(9.71)$ & $(7.52)$ & (9.38) & $(8.00)$ & (9.29) & $(9.42)$ & (8.08) & (8.92) & $(9.72)$ \\
\hline Marital status & & $66 \%$ & $70 \%$ & $66 \%$ & $74 \%$ & $75 \%$ & $71 \%$ & $68 \%$ & $77 \%$ & $71 \%$ \\
\hline \multirow{2}{*}{$\begin{array}{l}\text { Number of } \\
\text { children }\end{array}$} & Mean & 1.66 & 2.45 & 2.65 & 2.88 & 2.58 & 2.34 & 1.91 & 2.44 & 2.24 \\
\hline & $S D$ & $(1.21)$ & $(2.27)$ & (2.30) & (1.79) & (1.78) & $(1.81)$ & (1.93) & (1.89) & $(1.81)$ \\
\hline $\begin{array}{l}\text { Area of } \\
\text { residence }\end{array}$ & & $63 \%$ & $69 \%$ & $72 \%$ & $68 \%$ & $68 \%$ & $79 \%$ & $78 \%$ & $39 \%$ & $67 \%$ \\
\hline \multirow[t]{2}{*}{ Religiosity } & Mean & 1.41 & 2.66 & 2.42 & 1.94 & 2.17 & 1.70 & 1.96 & 2.40 & 1.97 \\
\hline & $S D$ & $(0.67)$ & $(0.57)$ & (1.08) & $(0.94)$ & $(0.92)$ & $(1.01)$ & (1.09) & $(0.82)$ & (0.99) \\
\hline $\begin{array}{l}\text { Academic } \\
\text { degree }\end{array}$ & & $49 \%$ & $30 \%$ & $54 \%$ & $49 \%$ & $35 \%$ & $61 \%$ & $57 \%$ & $43 \%$ & $48 \%$ \\
\hline $\begin{array}{l}\text { Full time } \\
\text { employment }\end{array}$ & & $78 \%$ & $80 \%$ & $62 \%$ & $71 \%$ & $73 \%$ & $75 \%$ & $69 \%$ & $66 \%$ & $72 \%$ \\
\hline PTM & & $31 \%$ & $23 \%$ & $47 \%$ & $49 \%$ & $36 \%$ & $57 \%$ & $55 \%$ & $41 \%$ & $44 \%$ \\
\hline \multirow[t]{2}{*}{ Income } & Mean & 7112.07 & 5165.66 & 7252.94 & 9372.95 & 7928.91 & 9796.26 & 8119.52 & 5513.21 & 7820.78 \\
\hline & $S D$ & (4753.90) & (3408.94) & (4780.68) & (5864.99) & (4933.26) & (5982.00) & (5322.67) & (3750.36) & (5206.46) \\
\hline
\end{tabular}

Imm., immigrants; Sec., second; Miz., Mizrahim; Ashk., Ashkenazim.

survey samples are based on random selection and the sampling method enables generalization of the results to the entire Israeli population $^{2}$

The total sample for the 2013, 2014, and 2015 surveys included about 21,000 respondents. From this sample we selected only employees aged 25-60 years old. Our final sample included 9,923 respondents: 1,600 Arabs and 8,323 Jews classified into seven groups (three Israeli-born groups and four immigrant groups). The final sample is presented separately by gender in Tables 1A,B.

\section{Variables}

\section{Dependent Variable}

To measure the mismatch between the subjective integration in the labor market and the actual position in it (subjective mismatch), we first calculated subjective and actual integration indices in the labor market.

The subjective integration index was measured by the mean of two items: (a) Are you satisfied with the income from your work? and (b) Are you satisfied with your job at your current (main) workplace? The scale of these two items was "1" - not satisfied at all, " 2 "- not very satisfied, "3"- satisfied, "4" - very satisfied. The correlation between these two variables was significant $(r=$ $0.428 ; p<0.00)$. The final variable was transformed into Z-score.

The actual integration index was measured as a mean of two variables: income and PTM (professional, technical, and

\footnotetext{
${ }^{2}$ When using official CBS data (in our case the CBS Social Survey), an ethics approval is not required by our academic institution's guidelines and national regulations. A written informed consent from the participants is also not needed when official national data is used:

http://www.cbs.gov.il/www/publications09/about/aboutcbs_e.htm
}

managerial) occupation ${ }^{3}$. Income was measured by the question: What was your gross salary last month, before deductions, from all places of work? This variable was measured by 10 categories and was transformed into a continuous variable using the midpoint of each group. This variable was transformed into the Z-score. PTM occupation was measured as a dichotomous variable coded "1," and " 0 " denoted other occupations. The correlation between these two variables was significant $(r=$ 0.396; $p<0.00)$. The final variable was standardized. The correlation between subjective and actual integration indices was significant $(r=0.433 ; p<0.00)$.

Our dependent variable, subjective mismatch, consists of three categories: positive subjective mismatch, matched, and negative subjective mismatch. If the respondent's subjective integration was at least half standard deviation above his actual integration it was defined as positive subjective mismatch, whereas if respondent's subjective integration was at least half standard deviation below his actual integration it was defined as negative subjective mismatch in the labor market. All other options were defined as matched.

\section{Independent Variables}

Gender was coded "1" for men and ' 0 ' for women.

Ethnicity combined four variables: population group (Jews or Arabs), country of birth, country of father's birth, and year of immigration. As a result, ethnicity included the following eight categories: (1) immigrants from the Former Soviet Union who arrived after 1989; (2) immigrants from Western countries

\footnotetext{
${ }^{3}$ This index is based on the measurement of labor market integration used in the Ruppin Index (Semyonov et al., 2007).
} 
TABLE 1B | Socio-demographic characteristics of the sample-Men.

\begin{tabular}{|c|c|c|c|c|c|c|c|c|c|c|}
\hline & & $\begin{array}{l}\text { FSU } \\
\text { Imm. }\end{array}$ & $\begin{array}{l}\text { Ethiop. } \\
\text { Imm. }\end{array}$ & $\begin{array}{l}\text { Western } \\
\text { Imm. }\end{array}$ & $\begin{array}{l}\text { Veteran } \\
\text { Imm. }\end{array}$ & $\begin{array}{l}\text { Sec. Miz. } \\
\text { Imm. }\end{array}$ & $\begin{array}{l}\text { Sec. Ashk. } \\
\text { Imm. }\end{array}$ & $\begin{array}{c}\text { Third } \\
\text { generation }\end{array}$ & Arabs & Total \\
\hline$N$ & & 727 & 75 & 102 & 275 & 1,247 & 618 & 1,169 & 1,051 & 5,264 \\
\hline Ethnicity & & $13.8 \%$ & $1.4 \%$ & $1.9 \%$ & $5.2 \%$ & $23.7 \%$ & $11.7 \%$ & $22.2 \%$ & $20.0 \%$ & $100 \%$ \\
\hline \multirow[t]{2}{*}{ Age } & Mean & 40.85 & 36.40 & 39.99 & 48.75 & 42.56 & 41.84 & 35.80 & 38.47 & 40.11 \\
\hline & $S D$ & $(9.94)$ & $(8.74)$ & $(9.86)$ & (8.35) & $(8.77)$ & (9.89) & (7.96) & $(9.15)$ & $(9.55)$ \\
\hline Marital status & & $67 \%$ & $55 \%$ & $68 \%$ & $83 \%$ & $78 \%$ & $72 \%$ & $66 \%$ & $81 \%$ & $73 \%$ \\
\hline \multirow[t]{2}{*}{ Number of children } & Mean & 1.41 & 2.15 & 2.59 & 3.05 & 2.42 & 2.26 & 1.68 & 2.66 & 2.18 \\
\hline & $S D$ & $(1.17$ & $(2.41)$ & $(2.58)$ & $(1.98)$ & $(1.76)$ & $(2.03)$ & $(1.83)$ & $(2.22)$ & $(1.95)$ \\
\hline Area of residence & & $62 \%$ & $76 \%$ & $73 \%$ & $66 \%$ & $67 \%$ & $77 \%$ & $77 \%$ & $40 \%$ & $65 \%$ \\
\hline \multirow[t]{2}{*}{ Religiosity } & Mean & 1.34 & 2.51 & 2.49 & 2.04 & 2.10 & 1.62 & 1.79 & 2.18 & 1.91 \\
\hline & $S D$ & $(0.63$ & $(0.69$ & $(1.06$ & $(1.03$ & $(0.92$ & $(0.99)$ & $(1.01)$ & $(0.87$ & $(0.96)$ \\
\hline Academic degree & & $42 \%$ & $4 \%$ & $51 \%$ & $37 \%$ & $28 \%$ & $52 \%$ & $44 \%$ & $19 \%$ & $35 \%$ \\
\hline Full time employment & & $90 \%$ & $93 \%$ & $76 \%$ & $85 \%$ & $86 \%$ & $87 \%$ & $82 \%$ & $87 \%$ & $86 \%$ \\
\hline PTM & & $31 \%$ & $8 \%$ & $54 \%$ & $46 \%$ & $38 \%$ & $56 \%$ & $53 \%$ & $18 \%$ & $39 \%$ \\
\hline \multirow[t]{2}{*}{ Income } & Mean & 10366.92 & 6646.67 & 10482.84 & 13113.64 & 11819.57 & 13738.27 & 11676.65 & 7712.18 & 10960.39 \\
\hline & $S D$ & $(5779.20$ & (3119.55 & (7224.33) & $(6855.66)$ & $(6181.24)$ & $(6969.14)$ & (6691.39) & $(4538.48)$ & (6390.66) \\
\hline
\end{tabular}

Imm., immigrants; Sec., second; Miz., Mizrahim; Ashk., Ashkenazim.

who arrived after 1989; (3) veteran immigrants who arrived in Israel before 1989; (4) first- and second-generation immigrants from Ethiopia; (5) Israeli-born who were born to fathers who immigrated to Israel from America or Europe, Ashkenazim; (6) Israeli-born who were born to fathers who immigrated to Israel from Asia or Africa, Mizrahim (excluding Ethiopia); (7) thirdgeneration, those born in Israel whose parents were born in Israel (served as the comparison group in the multivariate analyses); (8) Arabs-Israeli-born Arabs.

\section{Control Variables}

Age was measured in 5-year categories. This variable was transformed into a continuous variable using the midpoint of each group. We also added age-squared to the models to examine non-linear relationships between age and the dependent variable, forming the subjective mismatch.

Marital status was measured as a dichotomous variable: "1"married; "0"-other marital status.

Number of children was measured as a continuous variable.

Religiosity was measured on a scale of 1-4: "1"-not religious/secular; "2"-traditional; " 3 "-religious; "4"-very religious.

Area of residence was coded " 1 " for center residents (Haifa, Jerusalem, Tel Aviv, and the central region) and "0" for periphery residents (North, South, Judea and Samaria).

Education was measured by the highest diploma received by the respondent. This variable was transformed into a dichotomous variable: "1"-academic tertiary education and "0"-other education.

\section{RESULTS}

In this section we offer a descriptive analysis of our findings. Then, to obtain a deeper understanding of the descriptive results, we examine the multinomial logistic regression for the subjective mismatch in the labor market.

\section{Descriptive Analysis}

We first present the descriptive characteristics of the different ethnic groups in the study, separately for women (Table 1A) and men (Table 1B). In general, women are more educated than men: about $48 \%$ of women hold an academic degree compared to about $35 \%$ of men. The most educated groups, in terms of possessing an academic degree and holding more prestigious occupations (PTM), among both genders, were second-generation Ashkenazim, third-generation Israelis, and Western immigrants. The least educated groups holding the least prestigious occupations were Ethiopian immigrants, both men and women, and Arab men. The second-generation Mizrahim group cannot be classified as disadvantaged in terms of income compared to the average of the total sample. In general, women received significantly lower income than men. Among both genders, the second-generation Ashkenazim group was the highest paid group, whereas the lowest earning group was the Ethiopian immigrants.

Table 2 presents the descriptive statistics of the subjective and actual integration indices among different ethnic groups, separately by gender. As can be seen, among the total sample, gender differences in the subjective integration index were insignificant. However, among three ethnic groups (Arabs, thirdgeneration Israelis, and Ethiopian immigrants) a significant gender difference in the subjective integration index was found. In contrast, the gender difference in the actual integration index was significant both in the total sample and in almost all ethnic groups. Only among two ethnic groups (Arabs and Ethiopian immigrants) were the gender differences insignificant.

Figures 1, 2 present the percent of respondents for whom positive and negative subjective mismatches were detected 
TABLE 2 | Descriptive statistics of subjective and actual integration in the labor market by ethnicity and gender.

\begin{tabular}{|c|c|c|c|c|c|c|c|}
\hline & & \multicolumn{2}{|c|}{$\begin{array}{l}\text { Subjective integration } \\
\text { index }\end{array}$} & \multirow[t]{2}{*}{$T$-value } & \multicolumn{2}{|c|}{$\begin{array}{l}\text { Actual integration } \\
\text { index }\end{array}$} & \multirow[t]{2}{*}{$T$-value } \\
\hline & & Women & Men & & Women & Men & \\
\hline \multirow[t]{2}{*}{ FSU immigrants } & Mean & -0.28 & -0.24 & -0.98 & -0.30 & -0.02 & $-6.67^{\star \star}$ \\
\hline & $S D$ & $(0.82)$ & $(0.85)$ & & $(0.75)$ & $(0.83)$ & \\
\hline \multirow[t]{2}{*}{ Ethiopian immigrants } & Mean & -0.19 & -0.48 & $2.19^{\star \star}$ & -0.54 & -0.57 & 0.35 \\
\hline & $S D$ & $(0.81)$ & $(0.84)$ & & $(0.60)$ & $(0.46)$ & \\
\hline \multirow[t]{2}{*}{ Western immigrants } & Mean & 0.06 & 0.00 & 0.48 & -0.12 & 0.22 & $-2.79^{\star \star}$ \\
\hline & $S D$ & $(0.81)$ & $(0.85)$ & & $(0.73)$ & $(0.89)$ & \\
\hline \multirow[t]{2}{*}{ Veteran immigrants } & Mean & -0.01 & 0.01 & -0.23 & 0.08 & 0.35 & $-3.71^{\star \star}$ \\
\hline & $S D$ & $(0.75)$ & $(0.93)$ & & $(0.87)$ & $(0.91)$ & \\
\hline \multirow[t]{2}{*}{ Second generation Mizrahim } & Mean & 0.06 & 0.12 & -1.67 & -0.17 & 0.16 & $-10.35^{\star \star}$ \\
\hline & $S D$ & $(0.81)$ & $(0.81)$ & & $(0.75)$ & $(0.83)$ & \\
\hline \multirow[t]{2}{*}{ Second generation Ashkenazim } & Mean & 0.15 & 0.20 & -1.16 & 0.20 & 0.51 & $-6.46^{\star \star}$ \\
\hline & $S D$ & $(0.78)$ & $(0.79)$ & & $(0.82)$ & $(0.89)$ & \\
\hline \multirow[t]{2}{*}{ Third generation } & Mean & 0.04 & 0.15 & $-3.38^{\star \star}$ & 0.04 & 0.30 & $-7.76^{\star \star}$ \\
\hline & $S D$ & $(0.78)$ & $(0.78)$ & & $(0.76)$ & $(0.88)$ & \\
\hline \multirow[t]{2}{*}{ Arabs } & Mean & -0.01 & -0.25 & $4.86^{\star \star}$ & -0.32 & -0.38 & 1.64 \\
\hline & $S D$ & $(0.92)$ & $(0.97)$ & & $(0.71)$ & $(0.64)$ & \\
\hline \multirow[t]{2}{*}{ Total } & Mean & -0.01 & 0.00 & -0.017 & -0.10 & 0.10 & $-12.34^{\star \star}$ \\
\hline & $S D$ & $(0.82)$ & $(0.87)$ & & $(0.78)$ & $(0.87)$ & \\
\hline
\end{tabular}

${ }^{\star}$ Significant at $p \leq 0.05 ;{ }^{* *} p \leq 0.01$.

(respectively). As can be seen, there are gender differences in both mismatches: among women, a positive subjective mismatch of about $39 \%$ was detected compared to $31 \%$ among men $\left(\chi^{2}\right.$ $=66.55, p \leq 0.01$ ), and among women a negative subjective mismatch of $30 \%$ was detected compared to $36 \%$ among men $\left(\chi^{2}\right.$ $=39.04, p \leq 0.01)$. Moreover, significant gender differences were found for all ethnic groups (except for Ethiopian immigrants in both mismatches and among Arabs for negative mismatch). In other words, women were characterized by the positive subjective mismatch, whereas men were characterized by the negative.

Regarding ethnic differences in the positive subjective mismatch, the results show that among both genders, the highest percent of respondents for whom a positive subjective mismatch was detected occurred in the two groups with the lowest socioeconomic background: Ethiopian immigrants (48\% for women and $40 \%$ for men) and Arabs (49\% for women and $41 \%$ for men). These ethnic differences in the positive subjective mismatch were found significant $\left(\chi^{2}=55.72, p \leq 0.00\right.$ among women; $\chi^{2}=111.96, p \leq 0.00$ among men). Concerning the ethnic differences in the negative subjective mismatch, results show that among both genders, the highest percent of respondents for whom a negative subjective mismatch was detected was among the more settled ethnic groups: second-generation Ashkenazim ( $36 \%$ for women and $47 \%$ for men), veteran immigrants ( $36 \%$ for women and $47 \%$ for men) and third-generation Israelis (35\% for women only). These ethnic differences in the negative subjective mismatch were found significant $\left(\chi^{2}=67.08, d f=7, p \leq 0.01\right.$ among women; $\chi^{2}=84.07, d f=7, p \leq 0.01$ among men).
In addition, Figure 3 plots the share of the positive subjective mismatch against the negative subjective mismatch among 16 groups (8 ethnic groups $\times 2$ gender groups). The plot visualizes the negative association between the two mismatches (phi $=-0.52, p \leq 0.00$ ) and confirms the gender and ethnic heterogeneities among groups that were found previously.

\section{Multivariate Analyses}

Although the univariate descriptive analysis provides some insight into the gender and ethnic difference gaps in the positive and the negative subjective mismatches in the labor market, more elaborate models are necessary to test our research hypotheses related to gender and ethnic differences in positive and negative subjective mismatches.

We estimated a multinomial logit model for the probability of being positive or negative subjective mismatched vs. being matched. A positive coefficient in the model indicates the increase of the odds in favor of being positive or negative subjective mismatched, as opposed to matched, whereas a negative coefficient indicates the decrease of the odds. This multinomial regression was performed in three stages. In the first stage, dichotomous gender and ethnic variables were entered, and in the second stage the control socio-demographic variables were added. In the third and the final stage, we added the interaction effect between ethnicity and gender in order to investigate if the effect of ethnicity differs between genders. Our final regression model presented in Table 3 included only significant interactions.

In Table 3 we present the results of the multinomial logistic regression. First, we show the comparison between being positive 


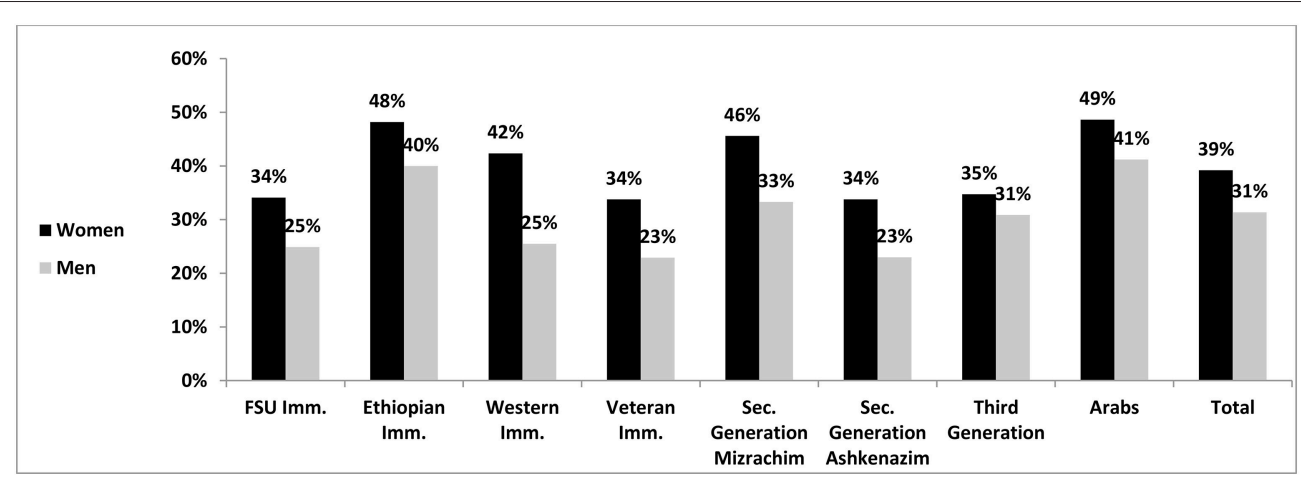

FIGURE 1 | Positive subjective mismatch in the labor market position by ethnicity and gender. Imm., immigrants; Sec., second; Miz., Mizrahim; Ashk., Ashkenazim.

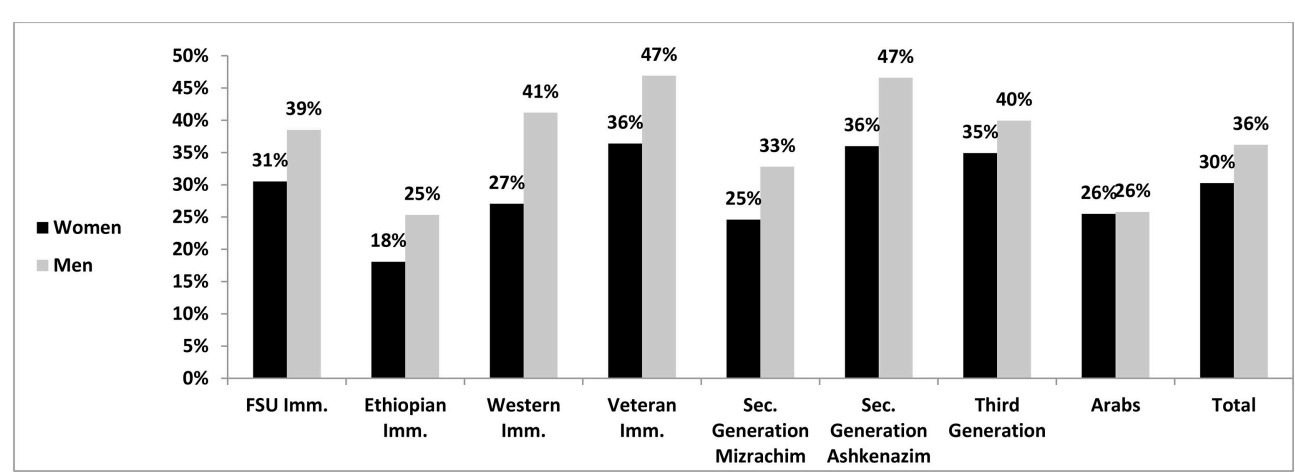

FIGURE 2 | Negative subjective mismatch in the labor market position by ethnicity and gender. Imm., mmigrants; Sec., second; Miz., Mizrahim; Ashk., Ashkenazim.

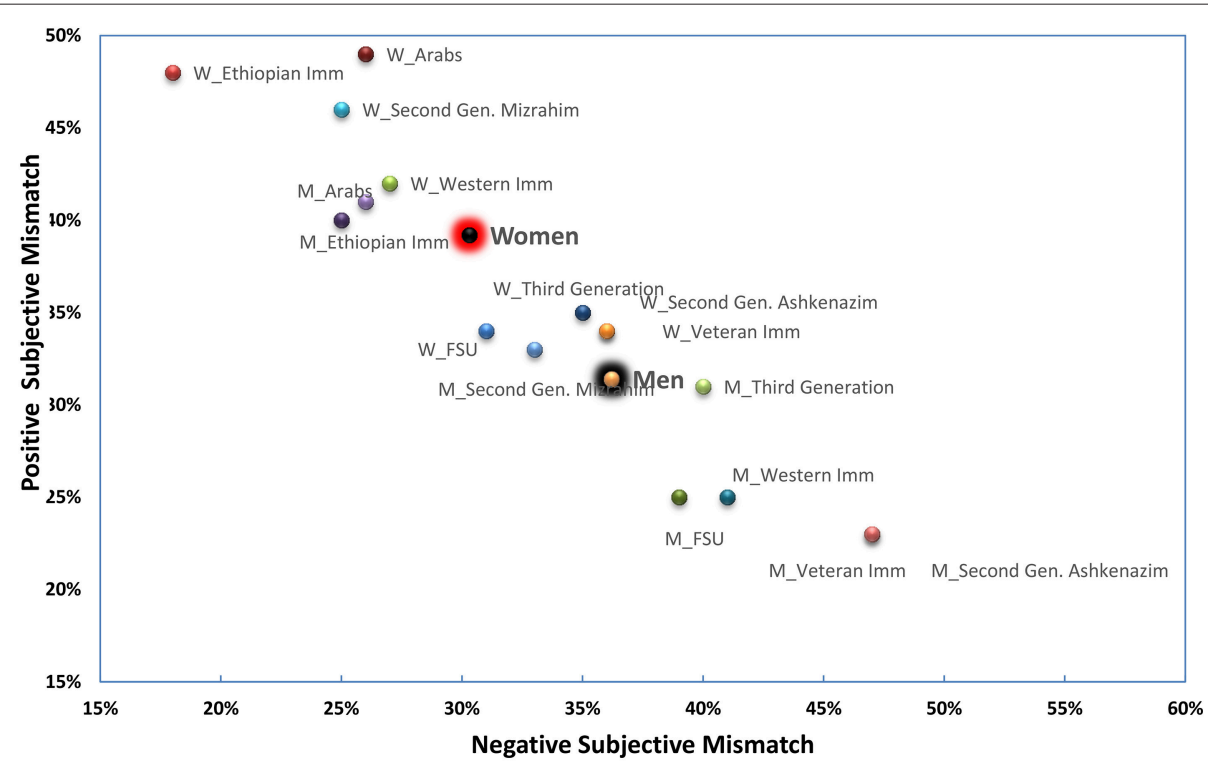

FIGURE 3 | Positive and negative subjective mismatches across different groups. W, Women; M, Men; Imm., immigrants; Miz., Mizrahim; Ashk., Ashkenazim. For example, M_Second Gen. Ashkenazim, Men Second Generation of Ashkenazim. 
TABLE 3 | Multinomial regression analysis for Subjective mismatch in the labor market: comparison group is "Matched."

\begin{tabular}{|c|c|c|c|c|c|c|c|c|c|c|c|c|}
\hline & \multicolumn{6}{|c|}{ Positive subjective mismatch vs. Matched } & \multicolumn{6}{|c|}{ Negative subjective mismatch vs. Matched } \\
\hline & \multicolumn{2}{|c|}{ Model 1a } & \multicolumn{2}{|c|}{ Model 2a } & \multicolumn{2}{|c|}{ Model 3a } & \multicolumn{2}{|c|}{ Model 1b } & \multicolumn{2}{|c|}{ Model 2b } & \multicolumn{2}{|c|}{ Model 3b } \\
\hline & B & $\operatorname{Exp}(B)$ & b & $\operatorname{Exp}(B)$ & B & $\operatorname{Exp}(B)$ & B & $\operatorname{Exp}(B)$ & B & $\operatorname{Exp}(B)$ & B & $\operatorname{Exp}(B)$ \\
\hline (Constant) & -0.07 & & $2.14^{\star \star}$ & & $2.16^{\star \star}$ & & $0.30^{\star \star}$ & & -0.92 & & -0.89 & \\
\hline Women & $0.33^{\star \star}$ & 1.39 & $0.43^{\star \star}$ & 1.51 & $0.41^{\star \star}$ & 1.51 & $-0.14^{\star}$ & 0.87 & $-0.30^{\star \star}$ & 0.74 & $-0.34^{\star \star}$ & 0.71 \\
\hline FSU Imm. & $-0.30^{\star \star}$ & 0.74 & $-0.25^{\star}$ & 0.78 & $-0.25^{\star \star}$ & 0.78 & $-0.27^{\star \star}$ & 0.76 & $-0.30^{\star \star}$ & 0.74 & $-0.30^{\star \star}$ & 0.74 \\
\hline Western Imm. & -0.05 & 0.95 & -0.07 & 0.93 & -0.07 & 0.93 & -0.16 & 0.86 & -0.22 & 0.81 & -0.22 & 0.81 \\
\hline Ethiopian Imm. & 0.15 & 1.17 & -0.06 & 0.95 & -0.06 & 0.95 & $-0.69^{\star \star}$ & 0.50 & -0.29 & 0.75 & -0.29 & 0.75 \\
\hline Veteran Imm. & -0.16 & 0.85 & -0.12 & 0.89 & -0.12 & 0.89 & 0.10 & 1.10 & 0.11 & 1.11 & 0.11 & 1.11 \\
\hline Sec. Generation Mizrahim & 0.11 & 1.12 & 0.06 & 1.06 & 0.06 & 1.06 & $-0.34^{\star \star}$ & 0.71 & $-0.21^{\star}$ & 0.81 & $-0.21^{\star \star}$ & 0.81 \\
\hline Sec. Generation Ashkenazim & -0.17 & 0.84 & -0.01 & 0.99 & -0.01 & 0.99 & 0.08 & 1.08 & -0.04 & 0.96 & -0.04 & 0.96 \\
\hline Arabs & $0.31^{\star \star}$ & 1.37 & 0.14 & 1.14 & 0.10 & 1.10 & $-0.43^{\star \star}$ & 0.65 & $-0.19^{*}$ & 0.82 & $-0.31^{\star \star}$ & 0.73 \\
\hline Age & & & $-0.08^{\star \star}$ & 0.92 & $-0.08^{\star \star}$ & 0.92 & & & 0.03 & 1.03 & 0.03 & 1.03 \\
\hline $\mathrm{Age}^{2}$ & & & $0.00^{*}$ & 1.00 & $0.00^{\star \star}$ & 1.00 & & & 0.00 & 1.00 & 0.00 & 1.00 \\
\hline Marital status (married = 1) & & & 0.02 & 1.02 & 0.02 & 1.02 & & & 0.06 & 1.06 & 0.06 & 1.06 \\
\hline Number of children & & & -0.03 & 0.97 & -0.03 & 0.97 & & & 0.03 & 1.03 & 0.03 & 1.03 \\
\hline Locality (center = 1) & & & $-0.25^{\star \star}$ & 0.78 & $-0.25^{\star \star}$ & 0.78 & & & $0.11^{*}$ & 1.12 & $0.11^{\star}$ & 1.12 \\
\hline Religiosity & & & $0.10^{\star \star}$ & 1.10 & $0.10^{\star \star}$ & 1.10 & & & $-0.10^{\star \star}$ & 0.91 & $-0.10^{\star \star}$ & 0.90 \\
\hline Full time employment & & & $-0.21^{\star \star}$ & 0.81 & $-0.21^{\star \star}$ & 0.81 & & & 0.12 & 1.13 & 0.13 & 1.14 \\
\hline Academic degree & & & $-0.89^{\star \star}$ & 0.41 & $-0.89^{\star \star}$ & 0.41 & & & $0.95^{\star \star}$ & 2.59 & $0.94^{\star *}$ & 2.57 \\
\hline Interaction: WomenArabs & & & & & 0.13 & 1.14 & & & & & $0.34^{*}$ & 1.41 \\
\hline Negelkerke R & 0.03 & & 0.18 & & 0.18 & & 0.03 & & 0.18 & & 0.18 & \\
\hline
\end{tabular}

"Significant at $p \leq 0.05 ; " * 0.01$.

subjective mismatch vs. matched, and then the results of being negative subjective mismatch vs. matched.

\section{"Being positive subjective mismatch" vs. "being matched"}

As was presented in the descriptive analyses, a positive subjective mismatch is more typical for women than for men (see Model 1a). The odds of a woman being a positive subjective mismatch vs. matched are more than 1.4 times higher compared to a man, $(\mathrm{B}=$ $0.33, \exp (\mathrm{B})=1.38, p<0.00)$. The log odds of positive subjective mismatch were significantly higher only among Arabs, $(B=0.31$, $\exp (B)=1.37, p<0.00)$, compared to those of third-generation Israelis, whereas among FSU immigrants were significantly lower, $(\mathrm{B}=-0.30, \exp (\mathrm{B})=0.74, p<0.00)$. Among other ethnic groups, the differences in log odds were insignificant compared to third-generation Israelis.

After controlling for socio-economic variables (see Model $2 \mathrm{a})$, the gender differences not only remained but even slightly increased, $(\mathrm{B}=0.43, \exp (\mathrm{B})=1.51, p<0.00)$. In contrast, the differences between Arabs and third-generation Israelis dropped to non-significant levels, and differences between FSU immigrants and third-generation Israelis slightly decreased, $(\mathrm{B}=$ $-0.25, \exp (B)=0.78, p<0.01)$. Therefore, these results support our hypothesis 1a (H1a) concerning the gender differences in the positive subjective mismatch, but do not support our hypothesis $2 \mathrm{a}(\mathrm{H} 2 \mathrm{a})$ concerning the ethnic differences in the positive subjective mismatch. In addition, employees who hold an academic degree, work full time, and live in the center were less characterized by a positive subjective mismatch. The effects of religiosity were found significant: a higher level of religiosity increased the log odds of positive subjective mismatch. The effect of age was parabolic. The interaction effects between gender and different ethnic groups were found insignificant (see Model 3).

\section{"Being negative subjective mismatch" vs. "being matched"}

As presented previously in the descriptive analyses and as can be seen in Model 1b, a negative subjective mismatch was less typical for women than for men $(B=-0.14, \exp (B)=0.87, p$ $<0.00)$. The log odds of negative subjective mismatch among FSU immigrants $(\mathrm{B}=-0.27, \exp (\mathrm{B})=0.76, p<0.00)$, Ethiopian immigrants $(B=-0.69, \exp (B)=0.50, p<0.00)$, second generation Mizrahim $(B=-0.34, \exp (B)=0.71, p<0.00)$ and Arabs $(\mathrm{B}=-0.43, \exp (\mathrm{B})=0.65, \mathrm{p}<0.00)$ were lower compared to those of third-generation Israelis. Among other ethnic groups the differences in log odds were insignificant compared to the third generation Israelis.

After controlling for socio-economic variables (see Model 2b), the gender differences increased $(B=-0.30, \exp (B)=0.74, p$ $<0.00$ ). The ethnic differences between Ethiopians and thirdgeneration Israelis dropped to non-significant levels, whereas the differences between FSU immigrants, $(B=-0.30, \exp (B)=0.74$, $p<0.00)$, second generation Mizrahim $(\mathrm{B}=-0.21$, $\exp (\mathrm{B})=0.81, p<0.00)$, Arabs $(\mathrm{B}=-0.19, \exp (\mathrm{B})=0.82, p$ $<0.05)$ and third-generation Israelis changed. In addition, only the interaction between gender and the Arab ethnic group was 
found positive and significant $(\mathrm{B}=0.34, \exp (\mathrm{B})=1.4, p<0.05)$ (see Model 3b). In other words, the ethnic differences between Arabs and the third-generation Israelis exist only among men, and gender differences in the negative subjective mismatch are not apparent among Arabs.

In sum, the results for most groups (except for Arabs) support our hypothesis $1 \mathrm{~b}(\mathrm{H} 1 \mathrm{~b})$ concerning the gender differences in the negative subjective mismatch, and partially support our hypothesis $2 \mathrm{~b}(\mathrm{H} 2 \mathrm{~b})$ concerning the ethnic differences in the negative subjective mismatch.

In addition, similar to the positive subjective mismatch findings, but in the opposite direction, the effects of academic degree, living in the center of the country, and the level of religiosity were found significant: employees who hold an academic degree, live in the center and have low level of religiosity were more characterized by a negative subjective mismatch.

\section{DISCUSSION}

In recent years, subjective parameters related to immigrants' satisfaction with their position in the labor market have been attracting more interest from migration scholars (Jong et al., 2002; Amit and Riss, 2014). However, no comprehensive study has been conducted that analyzes and compares subjective and objective parameters of immigrant labor market integration. The current study focuses on the mismatch between subjective work perceptions and actual labor market position from a gender and ethnic perspective. We examined two forms of this perceptional mismatch: positive and negative subjective mismatch. As far as we know, our study is the first to suggest this new conceptual framework.

The findings support our hypotheses $\mathrm{H} 1 \mathrm{a}$ and $\mathrm{H} 1 \mathrm{~b}$ concerning gender differences in both mismatches. A positive subjective mismatch was found to be more typical for women than for men, whereas a negative subjective mismatch was found to be more typical for men than women. In other words, women's subjective perceptions were higher than their actual position in the labor market, whereas men's subjective perceptions were lower than their actual position in the labor market. Moreover, after controlling for socio-economic variables, these gender differences in both mismatches even increased among all ethnic groups (except for Arabs in the negative subjective mismatch).

These findings correspond to the literature regarding the paradox of the contented female worker. According to this gender paradox, although women's jobs are generally less rewarding than men's jobs, women tend to be more satisfied with their jobs and their position in the workplace than men (Clark, 1997; Sousa-Poza and Sousa-Poza, 2007; Mora and Ferrer-i-Carbonell, 2009). One of the possible explanations for this phenomenon is gender differences in worker expectations. Women's work expectations are relatively lower than men's work expectations, thus women's higher job satisfaction is explained by women's perceived improved position in the labor market relative to their low expectations. Therefore, once women's expectations and perceptions related to their labor market position reach parity to those of men, their reported satisfaction should be identical as well (Clark, 1997). According to Clark (1997), women's relatively higher job satisfaction may be a transitory phenomenon. In line with this logic, gender differences in positive and negative subjective mismatches may also be a transitory.

Our hypotheses $\mathrm{H} 2 \mathrm{a}$ and $\mathrm{H} 2 \mathrm{~b}$ relate to ethnic differences in both mismatches. According to hypothesis $\mathrm{H} 2 \mathrm{a}$, a positive subjective mismatch is more apparent among disadvantaged ethnic groups with relatively lower socio-economic background compared to ethnic groups with relatively higher socioeconomic background. In this respect it is important to note that according to our findings, the actual position of second-generation Mizrahim in the labor market was relatively higher than we had expected based on previous studies (e.g., Semyonov et al., 2015). A recent report on wage stratification in Israel indicates that second-generation Mizrahim have improved their position dramatically and the two groups located at the bottom of the scale are Ethiopian immigrants and Arab citizens (Swirski et al., 2018). The findings indeed show that the highest percent of respondents for whom a positive subjective mismatch was detected was among Ethiopian immigrants and Arabs, groups with relatively lower socio-economic background. However, after controlling for socio-economic variables, the differences detected for Ethiopian immigrants and Arabs dropped to non-significant levels. Therefore, these results rejected our hypothesis $\mathrm{H} 2 \mathrm{a}$ concerning the ethnic differences in the positive subjective mismatch.

According to our hypothesis $\mathrm{H} 2 \mathrm{~b}$, a negative subjective mismatch is more apparent among advantaged ethnic groups with relatively higher socio-economic background compared to disadvantaged ethnic groups with relatively lower socioeconomic background. The findings show that log odds of negative subjective mismatch among FSU immigrants, Ethiopian immigrants, second-generation Mizrahim, and Arabs were lower compared to those of third-generation Israelis. However, after controlling for socio-economic variables, the ethnic differences between Ethiopians and Arabs (women only) compared to the third-generation Israelis dropped to non-significant levels, whereas the differences between FSU immigrants, secondgeneration Mizrahim, Arabs (men only) compared to the thirdgeneration Israelis changed slightly. This finding means that certain ethnic groups are less negative related to their actual position in the labor market compared to the third-generation Israelis. Thus, our hypothesis $\mathrm{H} 2 \mathrm{~b}$ concerning the ethnic differences in the negative subjective mismatch was partially supported.

As we learn from the findings, the subjective work perceptions of Arab men are in congruence with their objective position in the labor market (more matched and less negative compared to the third generation). This may be explained by a realistic view, without overly high expectations, of this clearly disadvantaged group in the Israeli labor market (Yashiv and Kasir, 2013). The same findings were obtained for second- generation Mizrahim. But in their case, although their objective position (in terms of education, occupation and income) in the labor market is 
average and even above average (as can be seen in Table 1B), they are satisfied with their objective position in the labor market, and therefore we can assume they do not express higher expectations compared to the third generation. A possible explanation of this finding may be that second-generation Mizrahim continue to perceive themselves as a disadvantaged group. This possible explanation should be further examined in future studies. As for FSU immigrants, in contrast to the second-generation Mizrahim, their responses tend to be balanced in both analyses (positive and negative subjective mismatch). In other words, there is a congruence between their objective position in the labor market and their subjective perceptions of it compared to third-generation immigrants. The case of FSU immigrants is unique, as they have a relatively high educational profile but are disadvantaged in the labor market in terms of occupation and income (as can be seen in Table 1B). This pattern points to the complexity of the FSU immigrant's position in the Israeli labor market, as they do not fit the typical behavior of both disadvantaged or advantaged groups. Notwithstanding these findings, we should consider that the level of work perceptions and expectations, as well as the objective position in the labor market, may change over time for the different groups. Therefore, the differences in positive and negative subjective mismatches may also be a transitory phenomenon (Clark, 1997).

Our findings also indicate that the positive and negative subjective mismatch patterns are not fully symmetrical. The gender gap can be symmetrically described by the positive and negative pattern, meaning that positive subjective mismatch is more typical for women than for men, and negative subjective mismatch is more typical for men than women. However, the ethnic gap cannot be symmetrically described. Whereas the ethnic gap is not detected in the positive subjective mismatch, it is partially detected in the negative one. This complex pattern related to ethnicity should be addressed and researched in future studies.

Another important finding is that employees who hold an academic degree, have a full-time job, and live in the center were less characterized by a positive subjective mismatch. In the opposite direction, but comparably to the findings related to the positive subjective mismatch, employees who hold an academic

\section{REFERENCES}

Aleksynska, M., and Tritah, A. (2013). Occupation-education mismatch of immigrant workers in Europe: Context and policies. Econ. Educ. Rev. 36, 229-244. doi: 10.1016/j.econedurev.2013.06.001

Amit, K. (2010). Determinants of life satisfaction among immigrants from Western countries and from the FSU in Israel. Soc. Indic. Res. 96, 515-534. doi: $10.1007 /$ s11205-009-9490-1

Amit, K. (2012). Social integration and identity of immigrants from western countries, the FSU and Ethiopia in Israel. Ethn. Racial Stud. 35, 1287-1310. doi: 10.1080/01419870.2011.602091

Amit, K., and Bar-Lev, S. (2015). Immigrants' sense of belonging to the host country: the role of life satisfaction, language proficiency, and religious motives. Soc. Indic. Res. 124, 947-961. doi: 10.1007/s11205-0140823-3 degree and live in the center were more characterized by a negative subjective mismatch. This may be explained by the fact that higher educated workers, those in professional or managerial positions, and those living in the center are all likely to have higher expectations about what their jobs should entail (Clark, 1997; Sousa-Poza and Sousa-Poza, 2007; Mora and Ferrer-iCarbonell, 2009). This finding may be in line with the structural explanation, according to which the paradox is more detectable in less prestigious occupations with a considerable number of female referents, and not in male-dominated occupations (Valet, 2018). Our findings may indicate that the differences in the positive and the negative subjective mismatches may be attributed to socioeconomic differences, and not merely to ethnic and gender differences. Future studies should continue exploring the changing dynamic of gender, ethnicity, migration and socioeconomic position in the Israeli context.

In addition, our findings point to a positive effect of religiosity on positive subjective mismatch and a negative effect of religiosity on negative subjective mismatch. These findings may be explained by subjective well-being studies indicating that certain aspects of religiousness (e.g., public religious involvement, intrinsic religious motivation) are positively related to individuals' subjective well-being (Blaine and Crocker, 1995; Smith et al., 2003).

This study's limitations are mainly a consequence of the limitations of the CBS social survey database. The CBS social surveys do not include questions regarding individual beliefs and expectations related to the labor market in general or to the individual's job in particular. The examination of employee beliefs and expectations may be pursued in future research, thus allowing us to specifically examine the impact of expectations and beliefs on the mismatch between the subjective and actual position in the labor market.

\section{AUTHOR CONTRIBUTIONS}

KA and SC-B contributed time and effort in writing this paper. $\mathrm{KA}$ contributed to the theoretical part of the paper and wrote the introduction section, whereas SC-B conducted the analyses and worth the methodology and results section. The discussion of the paper was written together.
Amit, K., and Litwin, H. (2010). The subjective well-being of immigrants aged 50 and older in Israel. Soc. Indic. Res. 98, 89-104. doi: 10.1007/s11205-0099519-5

Amit, K., and Riss, I. (2007). The role of social networks in the immigration decision-making process: the case of North American immigration to Israel. Immigr. Minor. 3, 290-313. doi: 10.1080/02619280802407517

Amit, K., and Riss, I. (2014). The subjective well-being of immigrants: pre-and post-migration. Soc. Indic. Res. 119, 247-264. doi: 10.1007/s11205-013-0492-7

Au, A., Garey, J., Bermas, N., and Chan, M. (1998). The relationship between acculturation and job satisfaction among Chinese immigrants in the New York city restaurant business. Int. J. Hospital. Manage. 17, 11-21. doi: 10.1016/S0278-4319(97)00040-6

Bartram, D. (2011). Economic migration and happiness: comparing immigrants' and natives' happiness gains from income. Soc. Indic. Res. 103, 57-76. doi: $10.1007 / \mathrm{s} 11205-010-9696-2$ 
Ben-Rafael, E., Lyubansky, M., Glöckner, O., Harris, P., Israel, Y., Jasper, W., et al. (2006). Building a Diaspora: Russian Jews in Israel, Germany and the USA. Leiden: Brill.

Blaine, B., and Crocker, J. (1995). Religiousness, race, and psychological wellbeing: exploring social psychological mediators. Personal. Soc. Psychol. Bull. 21, 1031-1041. doi: 10.1177/01461672952110004

Bloom, D. E., Grenier, G., and Gunderson, M. (1994). The Changing Labor Market Position of Canadian Immigrants. National Bureau of Economic Research. Working Paper No. 4672, Cambridge.

Borjas, G. J. (1990). Friends or Strangers: The Impact of Immigrants on the US Economy. New York, NY: Basic Books.

Castles, S., and Miller, M. (2013). The Age of Migration: International Population Movements in the in the Modern World. New York, NY: Guilford Press.

CBS (2007). Annual Data for 2017. Jerusalem: Israeli Central Bureau of Statistics.

Chachashvili-Bolotin, S. (2007). The Effects of Immigration on the Educational Attainments of Immigrants and Native Israelis. Tel Aviv University (Ph.D. thesis).

Chachashvili-Bolotin, S., and Lissitsa, S. (2016). Enrollment in religious schools and the educational achievements of children of high-skill immigrants. Int. Migrat. Rev. 52, 183-208. doi: 10.1111/imre.12266

Chevalier, A. (2003). Measuring over-education. Economica 70, 509-531. doi: 10.1111/1468-0335.t01-1-00296

Chiswick, B. R. (1982). "The economic progress of immigrants: some apparently universal patterns," in The gateway: U.S. Immigration Issues and Policies, ed B. R. Chiswick (Washington, DC: American Enterprise Institute for Public Policy Research), 119-158.

Chiswick, B. R., and Miller, P. W. (2002). Immigrant earnings: language skills, linguistic concentrations and the business cycle. J. Popul. Econ. 15, 31-57. doi: $10.1007 /$ PL00003838

Chiswick, B. R., and Miller, P. W. (2009). The international transferability of immigrants' human capital. Econ. Educ. Rev. 28, 162-169. doi: 10.1016/j.econedurev.2008.07.002

Chiswick, B. R., and Miller, P. W. (2012). Negative and positive assimilation, skill transferability, and linguistic distance. J. Hum. Cap. 6, 35-55. doi: $10.1086 / 664794$

Clark, A. E. (1997). Job satisfaction and gender: why are women so happy at work? Labour Econ. 4, 341-372.

Clark, A. E., Kristensen, N., and Westergård-Nielsen, N. (2009). Job satisfaction and co-worker wages: status or signal? Econom. J. 119, 430-447. doi: 10.1111/j.1468-0297.2008.02236.x

Cohen, Y., and Haberfeld, Y. (2007). Self-selection and earnings assimilation: immigrants from the Former Soviet Union in Israel and the United States. Demography 44, 649-668. doi: 10.1353/dem.2007.0023

Cohen, Y., and Kogan, I. (2007). Next year in Jerusalem... or in Cologne? Labour market integration of Jewish immigrants from the Former Soviet Union in Israel and Germany in the 1990s. Eur. Sociol. Rev. 23, 155-168. doi: 10.1093/esr/jcl026

Curran, S. R., Shafer, S., Donato, K. M., and Garip, F. (2006). Mapping gender and migration in sociological scholarship: Is it segregation or integration? Int. Migr. Rev. 40, 199-223. doi: 10.1111/j.1747-7379.2006.00008.x

Davison, H. K. (2014). The paradox of the contented female worker: Why are women satisfied with lower pay? Emp. Responsibil. Rights J. 26, 195-216. doi: 10.1007/s10672-014-9238-1

Diener, E. (1984). Subjective well-being. Psychol. Bull. 95 :542. doi: 10.1037/0033-2909.95.3.542

Diener, E., Emmons, R. A., Larsen, R. J., and Griffin, S. (1985). The satisfaction with life scale. J. Pers. Assess. 49, 71-75. doi: 10.1207/s15327752jpa4901_13

Ea, E. E., Griffin, M. Q., L'eplattenier, N., and Fitzpatrick, J. J. (2008). Job satisfaction and acculturation among Filipino registered nurses. J. Nurs. Schol. 40 46-51. doi: 10.1111/j.1547-5069.2007.00205.x

Gindin, R., Rosenbaum-Tamari, I., Rosenblum, A., Hershman, T., and Pozner, R. (2009). Patterns of Immigrant Absorption in Israel: Comparison Between Four Groups: Speakers of Russian, French, Spanish and English. Jerusalem: Myers-JDC-Brookdale Institute.

Gorodzeisky, A., and Semyonov, M. (2011). Two dimensions to economic incorporation: soviet immigrants in the Israeli labour market. J. Ethn. Migr. Stud. 37, 1059-1077. doi: 10.1080/1369183X.2011.572483
Groot, W., and Van Den Brink, H. M. (2000). Overeducation in the labor market: a meta-analysis. Econ. Educ. Rev. 19, 149-158. doi: 10.1016/S0272-7757(99)00057-6

Horn, J. E., Taris, T. W., Schaufeli, W. B., and Schreurs, P. J. (2004). The structure of occupational well-being: a study among Dutch teachers. J. Occup. Organ. Psychol. 77, 365-375. doi: 10.1348/0963179041752718

Jong, G. F., Chamratrithirong, A., and Tran, Q. G. (2002). For better, for worse: Life satisfaction consequences of migration. Int. Migr. Rev. 36, 838-863. doi: 10.1111/j.1747-7379.2002.tb00106.x

Khattab, N. (2002). Ethnicity and female labour market participation: a new look at the Palestinian enclave in Israel. Work Emp. Soc. 16, 91-110. doi: 10.1177/09500170222119263

Kogan, I. (2003). Ex-Yugoslavs in the Austrian and Swedish labour markets: the significance of the period of migration and the effect of citizenship acquisition. J. Ethn. Migr. Stud. 29, 595-622. doi: 10.1080/1369183032000123413

Leuven, E., and Oosterbeek, H. (2011). "Overeducation and mismatch in the labor market," in Handbook of the Economics of Education, Vol. 4, ed E. A. Hanushek, S. Machin, and L. Woessmann (Amsterdam: Elsevier Science), 283-326. doi: 10.1016/B978-0-444-53444-6.00003-1

Lewin-Epstein, N., and Semyonov, M. (1986). Ethnic group mobility in the Israeli labor market. Am. Sociol. Rev. 51, 342-352. doi: 10.2307/2095306

Lissitsa, S., and Chachashvili-Bolotin, S. (2016a). The less you know, the better you'll sleep-Perceived job insecurity in the Internet age. Comput. Human Behav. 62, 754-761. doi: 10.1016/j.chb.2016.05.006

Lissitsa, S., and Chachashvili-Bolotin, S. (2016b). Life satisfaction in the internet age-Changes in the past decade. Comput. Human Behav. 54, 197-206. doi: $10.1016 / j . c h b .2015 .08 .001$

Lissitsa, S., Peres, Y., and Ben-Rafael, E. (2002). "The attitude of the oldtimer to mmigrants from the CIS: The prospect of multiculturalism," in The Jews of the Former Soviet Union in Israel and the Diaspora, Vol. 20-21, ed L. Dimrsky-Zigelman (Jerusalem: Magnes Press), 187-205.

Lock, E. (1976). "The nature and cause of job satisfaction," in ed M. D. Dunette Handbook of Industrial and Organizational Psychology, (Chicago: Rand McNally), 1297-1349.

Luzzo, D. A., and McWhirter, E. H. (2001). Sex and ethnic differences in the perception of educational and career-related barriers and levels of coping efficacy. J. Counsel. Develop. 79, 61-67. doi: 10.1002/j.1556-6676. 2001.tb01944.x

Massey, D. S., and Akresh, I. R. (2006). Immigrant intentions and mobility in a global economy: the attitudes and behavior of recently arrived US immigrants. Soc. Sci. Q. 87, 954-971. doi: 10.1111/j.1540-6237.2006. 00410.x

McGowan, M. A., and Andrews, D. (2015). Skill Mismatch and Public Policy in OECD Countries. OECD Economics Department Working Papers, No. 1210, OECD Publishing, Paris.

McMichael, C., and Manderson, L. (2004). Somali women and well-being: social networks and social capital among immigrant women in Australia. Hum. Organ. 63, 88-99. Available online at: https://www.jstor.org/stable/44126994

McWhirter, E. H. (1997). Perceived barriers to education and career: Ethnic and gender differences. J. Vocat. Behav. 50, 124-140.

Mora, T., and Ferrer-i-Carbonell, A. (2009). The job satisfaction gender gap among young recent university graduates: evidence from Catalonia. J. Socio Econ. 38, 581-589. doi: 10.1016/j.socec.2009.02.003

Mueller, C. W., and Kim, S.-W. (2008). "The contented female worker: still a paradox?," in Justice, Vol. 25, eds K. A. Hegtvedt and J. Clay-Warner (Bingley: Emerald Group Publishing Limited), 117-149.

Nee, V., and Sanders, J. (2001). Understanding the diversity of immigrant incorporation: a forms-of-capital model. Ethn. Racial Stud. 24, 386-411. doi: $10.1080 / 01419870020036710$

Phinney, J. S., Horenczyk, G., Liebkind, K., and Vedder, P. (2001). Ethnic identity, immigration, and well-being: an interactional perspective. J. Soc. Issues 57, 493-510. doi: 10.1111/0022-4537.00225

Portes, A., and Rumbaut, R. G. (2006). Immigrant America: A Portrait. Los Angeles, CA: University of California Press.

Raijman, R., and Semyonov, M. (1997). Gender, ethnicity, and immigration: double disadvantage and triple disadvantage among recent immigrant women in the Israeli labor market. Gender Soc. 11, 108-125. 
Remennick, L. (2013). Professional identities in transit: factors shaping immigrant labour market success. Int. Migr. 51, 152-168. doi: 10.1111/j.1468-2435.2011.00733.x

Semyonov, M., Haberfeld, Y., Raijman, R., Amit, K., Dolevn S., BollotinChachashvili, A., et al. (2007). Ruppin Index for Immigrants' Integration in Israel - 2nd report. The Institute for Immigration and Social Integration, Ruppin Academic Center.

Semyonov, M., and Levin-Epstein, N. (1987). Hewers of Wood and Drawers of Water: Non-Citizen Arabs in the Israeli Labor Market. New York, NY: BLR Press.

Semyonov, M., Raijman, R., and Maskileyson, D. (2015). Ethnicity and labor market incorporation of post-1990 immigrants in Israel. Popul. Res. Policy Rev. 34, 331-359. doi: 10.1007/s11113-014-9345-6

Shabtay, M. (2001). Living with a threatened identity: life experiences with different color skin among Ethiopian immigrant children and adolescents in Israel. Megamot 41, 97-112. Available online at: https://www.jstor.org/stable/ 23657516

Shin, D. C., and Johnson, D. M. (1978). Avowed happiness as an overall assessment of the quality of life. Soc. Indic. Res. 5, 475-492.

Shinnar, R. S. (2007). A qualitative examination of Mexican immigrants' career development: perceived barriers and motivators. J. Career Dev. 33, 338-375. doi: $10.1177 / 0894845307300413$

Sicherman, N. (1991). "Overeducation" in the labor market. J. Labor Econ. 9, $101-122$.

Smith, T. B., McCullough, M. E., and Poll, J. (2003). Religiousness and depression: evidence for a main effect and the moderating influence of stressful life events. Psychol. Bull. 129, 614-636. doi: 10.1037/0033-2909.129.4.614

Solberg, E. C., Diener, E., Wirtz, D., Lucas, R. E., and Oishi, S. (2002). Wanting, having, and satisfaction: examining the role of desire discrepancies in satisfaction with income. J. Pers. Soc. Psychol. 83, 725-734. doi: 10.1037/0022-3514.83.3.725

Sousa-Poza, A., and Sousa-Poza, A. A. (2000). Well-being at work: a cross-national analysis of the levels and determinants of job satisfaction. J. Socio Econ. 29, 517-538. doi: 10.1016/S1053-5357(00)00085-8
Sousa-Poza, A., and Sousa-Poza, A. A. (2007). The effect of job satisfaction on labor turnover by gender: an analysis for Switzerland. J. Socio Econ. 36, 895-913. doi: 10.1016/j.socec.2007.01.022

Swirski, S., Konor-Atias, E., and Lieberman, A. (2018). Israel: A Social Report. Tel Aviv: Adva Center.

Tubergen, F. V., Mass, I., and Flap, H. (2004). The economic incorporation of immigrants in 18 western societies: origin, destination and community effects. Am. Sociol. Rev. 69, 704-727. doi: 10.1177/000312240406900505

Valdivia, C., and Dannerbeck, A. (2009). Moving around to get by and try to get ahead: immigration experiences in new settlement communities of the Midwest. Profess. Dev. Int. J. Contin. Soc. Work Educ. 12, 29-41.

Valdivia, C., and Flores, L. Y. (2012). Factors affecting the job satisfaction of Latino/a immigrants in the Midwest. J. Career Dev. 39, 31-49. doi: $10.1177 / 0894845310386478$

Valet, P. (2018). Social structure and the paradox of the contented female worker: how occupational gender segregation biases justice perceptions of wages. Work Occup. doi: $10.1177 / 0730888417753048$

Warr, P. (2013). "Jobs and job-holders: two sources of happiness and unhappiness," in The Oxford Handbook of Happiness, eds I. Boniwell, S. A. David, and A. Conley Ayers (New York, NY: Oxford University Press), 733-750.

Yashiv, E., and Kasir, N. (2013). Arab women in the Israeli labor market: characteristics and policy proposals. Israel Econ. Rev. 10, 1-41.

Conflict of Interest Statement: The authors declare that the research was conducted in the absence of any commercial or financial relationships that could be construed as a potential conflict of interest.

Copyright $\odot 2018$ Amit and Chachashvili-Bolotin. This is an open-access article distributed under the terms of the Creative Commons Attribution License (CC BY).

The use, distribution or reproduction in other forums is permitted, provided the original author(s) and the copyright owner(s) are credited and that the original publication in this journal is cited, in accordance with accepted academic practice. No use, distribution or reproduction is permitted which does not comply with these terms. 